DOI

\title{
СУЧАСНІ ІННОВАЦІЇ У ВІННИЦЬКОМУ НАЦІОНАЛЬНОМУ МЕДИЧНОМУ УНІВЕРСИТЕТІ ІМ. М. І. ПИРОГОВА ТА РЕАЛІЗАЦІЯ ЗАКОНУ УКРАЇНИ “ПРО ВИЩУ ОСВІТУ”
}

\author{
В. М. Мороз, Ю. Й. Гумінський, Л. В. Фоміна, Т. Л. Полеся \\ Вінницький національний медичний університет ім. М. І. Пирогова
}

\begin{abstract}
MODERN INNOVATIONS IN VINNYTSIA NATIONAL MEDICAL UNIVERSITY BY M. PYROGOV AND REALIZATOIN OF LAW OF UKRAINE “ABOUT HIGHER EDUCATION”
\end{abstract}

\author{
V. M. Moroz, Yu. Y. Huminskyi, L. V. Fomina, T. L. Polesya \\ Vinnytsia National Medical University by M. I. Pyrogov
}

\begin{abstract}
На сучасному етапі відбувається інтеграція вищої освіти України в Європейський освітній простір. Затверджений Закон України “Про вищу освіту” від 01.07.2014 р. передбачає впровадження сучасних європейських інноваційних технологій функціонування системи вищої освіти (принцип автономії вищих навчальних закладів, поєднання освіти з наукою, запровадження власних програм освітньої, наукової, науково-технічної та інноваційної діяльності та ін.). У ВНМУ ім. М. І. Пирогова згідно із Законом України “Про вищу освіту” реалізуються сучасні інноваційні технології організації навчального процесу - впроваджено Європейську кредитно-трансферну систему (ЄКТС), опанування навичок роботи з програмою “СКІФ”, Навчально-тренінговий центр практичної підготовки лікарів, елективний курс “Спортивні секції”, розроблена навчальна наскрізна програма “Фізична та психологічна реабілітація”.
\end{abstract}

At the modern stage there is integration of higher education of Ukraine in European educational space. Ratified Law of Ukraine “About higher education” from 1. 07. 2014 envisages introduction of modern European innovation technologies of functioning of the system of higher education (principle of autonomy of higher educational establishments, combination of education with science, input own programs of educational, scientific, scientific and technical and innovative activity and other). In connection of the integration of higher education of Ukraine in European educational space the Law of Ukraine ratified in a new release “About higher education” from 1.07.2014. In Vinnytsia National Medical University by M. Pyrogov from “On higher education" modern innovative technologies of organization of educational process will be realized - the European credit-transfer system (ECTS) is inculcated, capture of work skills with the program "SKIF", Study-training center of practical training of doctors, elective course the "Sporting sections", created study-education program by course "the Physical and psychological rehabilitation" is worked out.

Вступ. Інтеграція вищої освіти України у Європейський освітній простір полягає у корінних реформах вищої освіти, впровадженні сучасних інноваційних технологій організації навчального процесу, зміні парадигми навчання. Нові підходи до організації навчання базуються на принципах Болонської декларації, підписаної Україною. Одним з інструментів реалізації цілей євроінтеграції освіти $є$ запровадження в навчальний процес вищих навчальних закладів Європейської кредитно-трансферної системи (ЄKTC), яка забезпечує вузам досягнення якості освіти, в тому числі й медичної. Метою запровадження Європейської кредитно-трансферної системи є створення уніфікованих критеріїв і методологій та систем контролю, взаємовизнання ди-

С В. М. Мороз, Ю. Й. Гумінський, Л. В. Фоміна, Т. Л. Полеся пломів про вищу освіту, забезпечення мобільності студентів. У світлі євроінтеграції затверджений Закон України “Про вищу освіту” від 01.07.2014 р. № 1556-VII [1]. Закон встановлює основні правові, організаційні, фінансові засади функціонування системи вищої освіти, створює умови на принципах автономії вищих навчальних закладів, поєднання освіти 3 наукою та виробництвом, самореалізації особистості, забезпечення потреб суспільства, ринку праці та держави у кваліфікованих фахівцях. Одним із найважливіших стратегічних завдань вищої освіти України відповідно до прийнятого Закону України $\epsilon$ впровадження сучасних інноваційних технологій навчання, за Європейською кредитно-трансферною системою (ЄКТС), впровадження нових освітніх програм [2]. 
Основна частина. У ВНМУ ім. М. І. Пирогова у зв’ язку з набуттям чинності Закону України “Про вищу освіту” процес поетапної імплементації основних положень Закону України почався ще 3 2009 навчального року згідно з наказом МОН України від 16.10.2009 р. № 943 та листом МОН України від 26.02.2010 р. № 1/9-119, було запроваджено основні засади Європейської кредитнотрансферної системи (ЄKTC) [5]. У новій редакції Закону України “Про вищу освіту” (далі - Закон) сказано, що “...вищий навчальний заклад є окремим видом установи, яка є юридичною особою приватного або публічного права, діє згідно з виданою ліцензією на провадження освітньої діяльності на певних рівнях вищої освіти, проводить наукову, науково-технічну, інноваційну та/або методичну діяльність, забезпечує організацію освітнього процесу і здобуття особами вищої освіти, післядипломної освіти з урахуванням їхніх покликань, інтересів і здібностей” [1]. 3 2014-2015 навчального року і далі основні статті Закону набули чинності та згідно з останньою редакцією (від 28.06.2015 р., підстава 222-19) імплементуються 3 2015-2016 навчального року [1]. Стаття 7. Документи про вищу освіту (наукові ступені). У разі здобуття особою вищої освіти за спеціалізацією ВНМУ ім. М. І. Пирогова надає диплом спеціаліста та додаток до диплома європейського зразка, що містить структуровану інформацію про завершене навчання, а саме відомості про назви дисциплін, отримані оцінки і здобуту кількість кредитів ЄKTC, а також національну систему вищої освіти України. Стаття 10. Стандарти вищої освіти. У ВНМУ ім. М. І. Пирогова на підставі освітньопрофесійної програми за кожною спеціальністю діє навчальний план, який визначає перелік та обсяг навчальних дисциплін у кредитах ЄKTC, на навчальний рік затверджується робочий навчальний план, що відображає інновації, впроваджені у ВНМУ ім. М. І. Пирогова, а саме з 2015-2016 навчального року програма передбачає впровадження елективного курсу на кафедрі фізичного виховання та ЛФК “Спортивні секції” і надання відповідних годин. Студенти всіх курсів отримали право на вибір брати участь у спортивних секціях будьякого напрямку, що сприяє вихованню та пропаганді серед майбутніх лікарів здорового способу життя. Для оптимізації та покращення якості освіти впроваджені зміни в організації навчального процесу: повернення виробничої літньої лікарської практики студентів 4 та 5 курсів за розробленою фахівцями університету програмою з виробничої практики, впроваджується проведення літньої практики в країнах Європейської шенгенської зони, а саме в Польщі, Німеччині, Чехії та ін. Для полегшення конвертації оцінок у бали для всіх дисциплін введено уніфіковану шкалу оцінювання успішності студентів перерахунку традиційних оцінок 3 5-бальної системи у європейську бальну шкалу оцінювання в системі ЄKTC [2]. На кафедрах дисциплін з предметів ліцензійних тестових іспитів Крок-1, Крок-2 та Крок-3 впроваджено проведення класичних іспитів. Таким чином, оцінка 3 дисципліни складається з багатьох показників, а саме 3 поточних занять, підсумкових проміжних контролів з модулів та екзаменаційної оцінки, середня арифметична перекладається на оцінку в балах щодо шкали системи ECTS, що унеможливлює суб’єктивний підхід щодо оцінювання знань студентів на іспитах. Створення уніфікованих критеріїв, стандартів навчання та систем контролю полягає у впровадженні основних положень ЄКТС [3], а саме взаємовизнання дипломів про вищу освіту, мобільність студентів, наявність ключових документів для вищих навчальних закладів (Каталог курсів, Аплікаційна форма студента, Угода про навчання, Угода про практичну підготовку та зобов’язання про якість, Академічна довідка, Додаток до диплома європейського зразка та ін.). Стаття 16. Забезпечення якості вищої освіти. У світлі системи внутрішнього забезпечення якості освіти з метою покращення якості навчання у ВНМУ ім. М. І. Пирогова організований додатковий орган контролю якості знань студентів - Відділ моніторингу якості освіти, функції якого полягають у постійному контролі якості освіти на всіх етапах навчального процесу, включно і складання попередніх та передекзаменаційних тестувань студентами (інтернами). Відбувається постійний моніторинг, перевірка знань студентів та якості викладання викладачами дисциплін Крок-1, Крок-2 та Крок-3. Відділ моніторингу якості здійснює організаційно-технологічну підготовку, проведення тестування, обробку бланків відповідей, визначення та оголошення результатів тестувань, визначення та аналіз статистичних показників результатів тестувань, інформування ректорату університету. Стаття 26. Основні завдання вищого навчального закладу. Основними завданнями вищого навчального закладу є... забезпечення органічного поєд- 
нання в освітньому процесі освітньої, наукової та інноваційної діяльності. 3 метою покращення практичної підготовки студентів та оптимізації методики опанування практичних навичок на базі ВНМУ iм. М. I. Пирогова створений Тренінговий центр для опанування практичних навичок студентами та інтернами на базі запровадження сучасних тренажерів (у т. ч. комп’ютерних тренажерів програми “СКІФ”), муляжів, фантомів, імітаторів для діагностики, лікування та профілактики різних нозологій, Інтернет-технології з наданням пріоритету загальній практиці - сімейній медицині. Викладачі клінічних кафедр університету приділяють увагу оволодінню студентами практичними навичками та професійними вміннями, особлива увага акцентується на діагностику невідкладних станів та надання медичної допомоги на догоспітальному етапі у дорослих і дітей згідно зі стандартами та протоколами МОЗ України. Закон України “Про вищу освіту”. Стаття 32. Діяльність вищого навчального закладу проводиться на принципах автономії та самоврядування. Вищі навчальні заклади мають рівні права, що становлять зміст їх автономії та самоврядування, у тому числі мають право: розробляти та реалізовувати освітні (наукові) програми в межах ліцензованої спеціальності; самостійно визначати форми навчання та форми організації освітнього процесу; приймати на роботу педагогічних, наукових, науково-педагогічних та інших працівників; формувати та затверджувати власний штатний розпис; самостійно розробляти та запроваджувати власні програми освітньої, наукової, науково-технічної та інноваційної діяльності. У ВНМУ ім. М. І. Пирогова провідними фахівцями розроблена та очікує на затвердження наскрізна програма “Фізична та психологічна реабілітація”. Інноваційна пропозиція від ВНМУ: згідно з новою програмою запропоновано МО3 України ввести штатну одиницю медичного реабілітолога-психолога у всі відділення медичних лікувальних закладів незалежно від кількості лікувальних ліжкомісць. Згідно зі ст. 32, діяльність вищого навчального закладу проводиться на принципах автономії та самоврядування, в тому числі самостійне проведення фінансово-господарської та іншої діяльності відповідно до законодавства та статуту вищого навчального закладу, а також можливість для університетів розпоряджатися власними надходженнями, зокрема надання платних послуг, відкривати поточні та депозитні рахунки в банках. На сучасному етапі при наявності підпорядкування медичних університетів МОНу та МОЗу України не $є$ можливою фінансово-господарська діяльність за неузгодженими положеннями Кабінету Міністрів України та вищих навчальних закладів. Cmamтя 33. Структура вищого навчального закладу. Вищий навчальний заклад, що готує фахівців медичного та фармацевтичного профілів... спільно 3 центральними органами виконавчої влади..., органами місцевого самоврядування можуть утворювати на базі наукових установ, закладів охорони здоров’я, у тому числі тих, що належать територіальним громадам або передані їм, клінічні бази закладів медичної освіти, університетські клініки та лікарні. На сучасному етапі майже всі медичні університети України не мають університетських клінік, що складає проблему для опанування студентами клінічних дисциплін. На даний час студенти відпрацьовують практичні навички на клінічних базах міських лікарень, які вимагають орендної плати за надання приміщень, а також інші фінансові претензії до університетів. Стаття 46. Автономія вищого навчального закладу - це самостійність, незалежність і відповідальність вищого навчального закладу у прийнятті рішень стосовно розвитку академічних свобод, організації наукових досліджень, освітнього процесу, внутрішнього управління, економічної та іншої діяльності, самостійного добору і розстановки кадрів у межах, передбачених цим Законом. Права вищого навчального закладу, що визначають зміст його автономії, визначаються Законом України “Про вищу освіту” і не можуть бути обмежені іншими законами та нормативно-правовими актами. У ВНМУ ім. М. І. Пирогова згідно із засадами автономії відбуваються оптимізація навчального процесу шляхом впровадження інноваційних технологій навчання, в тому числі й дистанційних (лекції, семінари, Інтернет-конференції), оновлення навчальних програм, вдосконалення навчальнометодичної роботи. Стаття 56. Робочий час науково-педагогічних, наукових і педагогічних працівників. Максимальне навчальне навантаження на одну ставку науково-педагогічного працівника не може перевищувати 600 годин на навчальний рік. У ВНМУ ім. М. І. Пирогова у перехідний період 3 1 вересня 2015 р. педагогічне навантаження зменшено до 650 годин. В 2016-2017 навчальному році буде приведено до чинного Закону - 600 годин на викладача на рік згідно зі скороченням педагогіч- 
ного навантаження на викладачів. У ВНМУ ім. М. І. Пирогова отримані з ЦМК МОЗ України навчальні плани із змінами щодо розподілу годин по дисциплінах. Створені нові робочі програми із скороченням годин на 10 - 20 \% за рахунок збільшення кількості годин на самостійну роботу студента (СРС) з кожної дисципліни, що надало можливість скоротити навантаження викладачів 3 900 годин до передбачуваних 600 годин, таким чином, на вимогу Кабміну України зменшення максимального навчального навантаження на одну ставку науково-педагогічного працівника до 600 годин на навчальний рік не $є$ підставою для збільшення чисельності штатних одиниць. Cmammя 75. Основні напрями міжнародного співробітництва у сфері вищої освіти. Основними напрямами міжнародного співробітництва вищих навчальних закладів є участь у програмах двостороннього та багатостороннього міждержавного і міжуніверситетського обміну студентами, аспірантами, докторантами, педагогічними, науково-педагогічними та науковими працівниками, проведення спільних наукових досліджень..., участь у міжнародних освітніх та наукових програмах, укладають договори про співробітництво, встановлюють прямі зв’язки з вищими навчальними закладами, науковими установами та підприємствами іноземних держав, міжнародними організаціями, фондами тощо відповідно до законодавства. Згідно зі cm. 32, 75 ВНМУ ім. М. І. Пирогова бере участь у міжнародних програмах. Протягом наступних 3-х років ВНМУ реалізовуватиме багатонаціональний проект, учасниками якого є 19 університетів з різних країн: ПРОЕКТ 530644-TEMPUS-1-2012-1-ES-TEMPUSJPCR HUMAN Security. Безпека людини на територіях, забруднених радіоактивними речовинами, фінансуватиметься при підтримці Європейської комісії. Загальна вартість проекту 1410 095,22 євро. Грант-холдером та координатором проекту $€$ University of Cordoba, Іспанія. За прогнозами, попит на вищу освіту через 10-15 років у світі становитиме близько 230-300 млн осіб, що вимагає надзвичайно конкурентної високоякісної освіти. У ВНМУ ім. М. І. Пирогова для підвищення

\section{Список літератури}

1. Закон України “Про вищу освіту” від 01.07.2014 р. № 1556-VII (Редакція станом на 01.07.2014 р.). - zakon. Rada.gov.ua. конкурентоспроможності та якості освіти приділяється увага розвитку професійного рівня науковопедагогічного персоналу, залученню нових технологій освіти, нових форм контролю, моніторингу знань студентів. Розробляється система інтеграції практичної та науково-дослідницької діяльності у світлі європейської академічної тріади діяльності університетів - поєднання педагогічного процесу, наукових досліджень та клінічної практики [4]. Планується налагодити контакти з вузамипартнерами Європи та започаткувати обмін студентами та викладачами для взаємовизнання дипломів про вищу освіту.

Висновки. Таким чином, реалізація статей Закону України “Про вищу освіту” уніфікує національну освітню систему України з країнами Європи згідно з європейськими стандартами [4]. Реформи у вищих навчальних закладах відбуваються в національних рамках у світлі положень ЄКТС, що дає можливість з боку держави надати кожному студенту шанс здобути освіту світового рівня, стати конкурентоспроможним фахівцем та мати можливість вибору місця праці у будь-якій країні. У ВНМУ ім. М. І. Пирогова реалізація основних статей Закону України “Про вищу освіту” полягає у запровадженні інноваційних технологій організації навчального процесу. Кінцевою метою впровадження нових європейських технологій є взаємовизнання результатів навчання та дипломів про вищу освіту [2]. Реформування медичної освіти України згідно $з$ новим Законом “Про вищу освіту” - це можливість для майбутнього лікаря стати конкурентоспроможним фахівцем та обирати місце праці у будь-якій країні Європи. Зважаючи на європейський вектор розвитку, майбутня система охорони здоров'я в Україні узгоджується з європейськими стандартами, що передбачає впровадження сучасних світових схем, практик та досвіду. Головним напрямком розвитку вищої медичної освіти України є постійне підвищення якості освіти, оновлення її змісту та форм організації навчально-виховного процесу у світлі державно-суспільної системи; інтеграції вищої освіти України у міжнародне науково-освітнє співтовариство.

2. Довідник користувача ЄКТС 2009. Брюссель, 6 лютого 2009 р. - http://www.bologna2009benelux.org. Вебсторінка секретаріату Болонського процесу, Бенілюкс 2009. - http://www.bologna2009benelux.org. 
3. Визначення критеріїв якості в системі безперервного професійного розвитку лікарів та провізорів на основі концепції кредитів / Ю. В. Вороненко, А. М. Сердюк [та ін.] // Медична освіта. - 2007. № 3. - С. 11-15.

4. Комюніке Конференції міністрів європейських країн, відповідальних за сферу вищої освіти (Лондон, 16-19 травня 2007 р.). - К., 2008. - Кн. 4: Основні засади розвитку вищої освіти України. - С. 24-30.
5. Методичні рекомендації щодо запровадження Європейської кредитно-трансферної системи та її ключових документів у вищих навчальних закладах (лист МОН України від 26.02.2010 р. № 1/9-119); наказ МОН України від 16.10.2009 р. № 943 про запровадження у всіх вищих навчальних закладах України Європейської системи ЄКТС. 